\title{
Analysis of Factors Affecting Bond Prices Traded on Indonesia Stock Exchange in the Period 2016-2018
}

\author{
Hastri Nurdianti ${ }^{1}$, Bambang Santoso Marsoem , Ph.D ${ }^{2}$ \\ ${ }^{1}$ Master of Management, Mercu Buana University, Jakarta, Indonesia \\ ${ }^{2}$ Lecturer of Postgraduate, Mercu Buana University, Jakarta, Indonesia
}

\begin{abstract}
This study aims to analyze the effect of Coupons, Maturity Period, Current Ratio and Bond Rating on corporate bond prices. The study population consists of corporate bonds traded on the Indonesia Stock Exchange for the period 2016-2018. The sample selection technique was carried out by purposive sampling. The research sample consisted of 45 corporate bonds issued by 20 companies from all sectors except the banking and financial sectors. The research analysis method used is descriptive statistics and Common Effect Model (CEM) panel data regression. The results showed that partially the Coupon, Maturity Period and Bond Rating variables had a significant positive effect on Bond Prices, while the Current Ratio variable had a significant negative effect on Bond Prices. The implication of this research is that companies as bond issuers are advised to pay attention to the factors that affect bond prices, especially coupons, maturity and bond ratings in order to provide an appropriate price release for the bonds issued. By paying attention to factors, one of which is increasing the bond rating can maintain investor confidence. This is because these variables are proven to have an effect on Bond Prices. For further research, it is expected to study other variables that affect bond prices because the coefficient of determination of this study is $67 \%$, meaning that there are $33 \%$ variations in bond prices explained by other variables outside of the study.
\end{abstract}

Keywords:- Coupons, Maturity Period, Current Ratio, Bond Rating, Bond Price.

\section{INTRODUCTION}

Bond investment is a type of investment that is in great demand by investors (owners of capital) because bonds have fixed income. The fixed income is obtained from the principal of the bonds and interest which will be received periodically at maturity. Bond issuance is carried out by companies that need funds, both for business expansion and to meet the company's long-term or shortterm financial needs.

The main objective of an investor to invest in a financial instrument is to get a return (yield). For investors, when buying bonds, investors will receive fixed interest / coupons on a regular basis, usually every 3 months, 6 months, or once a year until maturity. Returns in the form of capital gains may also be obtained by bondholders. If a bond is bought at par and sold at a premium, it will provide capital gains for the holder. Data on the development of the Indonesian bond market in 2011 to 2018 can be seen in Figure 1.1 below.

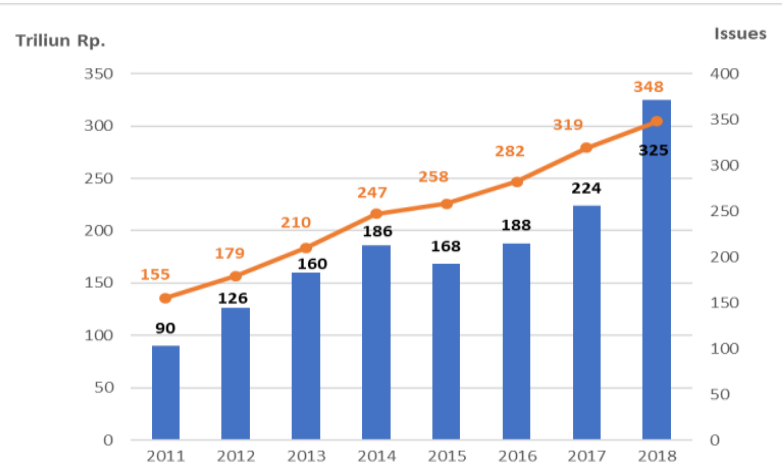

Fig 1:- Value of Corporate Bonds and Issues for the Period of 2011-2018

Source: Indonesia Stock Exchange (2018)

Figure 1 shows an increase in the value of corporate bonds in 2016 by $12 \%$ from IDR 168 Trillion to IDR 188 Trillion, and in 2017 it was $21 \%$ to IDR 224 Trillion. The increase occurred in 2018, namely $41 \%$ to Rp 325 trillion, followed by an increase in the number of bonds (issues) issued by the corporation began t ear 2011 as many as 155 to 2018 noted there were 348 issues. This condition indicates that market confidence in corporate bonds is quite high.

According to the Indonesia Bond Pricing Agency (IBPA), the surge in corporate bond issuance in this sector cannot be separated from the government's focus on the infrastructure sector according to the 2015-2019 RPJMN that infrastructure funding relies on SOE funding and private funding (source: Bisnis.com). The trend above shows that investor interest in corporate bonds is getting higher because corporate bond yields are also high (Indarsih, 2013). Based on secondary data from the Indonesia Stock Exchange (2018) regarding Bond Prices and Yield To Maturity between the Government and corporations in the 2014-201 Period, it shows that the comparison of corporate bond prices has a quite different ratio compared to government bond prices. Judging from the annual average, the price of corporate bonds has an average value of $100,451 \%$, while government bonds are $103,791 \%$. The price of government bonds is higher than the price of corporate bonds. Based on this, it can be seen that the price of corporate bonds has increased and decreased during that period. This makes the researchers examined te ntang corporate bond prices and the reasons for choosing the sector non-financial is 
because based on the data recorded on the stock exchanges of Indonesia, the number of corporations that issue to kan bonds and traded the period 2016-2018 is dominated by non-financial companies. Based on the IDX Yearly Statistics 2018, there were 58 non-financial sector companies and 25 financial sector companies. This is what led to choosing a non-financial company.

Factors that can affect changes in bond prices according to Fabozzi (2000: 569) are the level of bond liquidity, maturity, and coupons. The factors used in this study are coupons, maturity, liquidity, and rating. Here it is $\mathrm{n}$ use values the average of each variable during the study period.

\begin{tabular}{|c|c|c|c|c|c|}
\hline Year & $\begin{array}{c}\text { Price } \\
\text { Bond }\end{array}$ & Coupon & $\begin{array}{c}\text { Period } \\
\text { of time }\end{array}$ & CR & Rating \\
\hline 2016 & $100.92 \%$ & $9.8 \%$ & 5.96 & 1.52 & 9.06 \\
\hline 2017 & $102.73 \%$ & $9.9 \%$ & 4.96 & 1.37 & 8.99 \\
\hline 2018 & $101.83 \%$ & $9.7 \%$ & 3.96 & 1.40 & 9,10 \\
\hline
\end{tabular}

Table 1:- Average ( Mean ) of Research Variables

Source: Secondary data that has been processed by the author (2019)

Based on the data in table 1, the following is the relationship between the variable Bond Prices and Coupons, Maturity Period, Current Ratio and Rating as follows:

$>$ The average bond price at companies listed on the IDX during the 2016-2018 period fluctuated where in 2016 the average bond price was $100.92 \%$, In 2017 the average bond price increased by $102.73 \%$, Meanwhile in 2018 the average bond price decreased by $101.83 \%$.

The average value of the coupon variable in companies listed on the IDX during the 2016-2018 period fluctuated where in 2016 the average was $9.8 \%$, In 2017 the average was $9.9 \%$, while in 2018 an average of $9.7 \%$. A high bond coupon value will make the bond attractive to investors because a high coupon value will result in higher yiled .

$>$ The average time period variable based on companies listed on the IDX during the 2016-2018 period has decreased where in 2016 the average time period was $5.96 \%$, In 2017 the average time period decreased by 4, 96\%, while in 2018 the average return period decreased to $3.96 \%$. The maturity date of the bonds is the time determined by the company for the bonds it issues or the time it takes the company to fulfill its obligations. When the bonds have reached maturity, the value will decrease due to the minimum remaining interest payments on the bonds.

$>$ The Average on variable current ratio based on the companies listed on the Stock Exchange during the period 2016-2018 experienced a fluctuation where in 2016 the average current ratio of $1.52 \%$, p there in 2017 the average current ratio decreased to of $1,37 \%$, while in 2018 the average current ratio increased again to 1.40 . Liquidity is a company's ability to pay its short-term obligations, if the company cannot pay off its debt properly, it will affect the price of the bonds to be issued because investors do not want to accept the risk if later selling bonds can be lower than the purchase price.

$>$ The average on variable ranking based on companies listed on the Stock Exchange during the period 20162018 fluctuated where in 2016 an average rating of 9.06 , In 2017 the average decreased to by 8.99 , while in 2018 again increased to 9,10 . A good rating not only shows the company's ability to pay off its obligations, but also shows that the company's performance is effective and efficient because it is able to manage debt for the progress of its business .

Several studies related to the Effect of Coupons, Maturity Period, Current Ratio and Rating on Bond Prices still have a research gap where the results of several previous studies tend to be inconsistent or different from one researcher to another, as shown below:

$>$ In research by Dewi et al (2016), Sari and Sudjarni (2016), Anandasari and Sudjarni (2017), Ompusunggu (2012), Linda et al (2017), Ekak and Abudanti (2011), Danemadkk (2013) and Krisni lasari (2007 coupon has a positive impact on bond prices. Things are different at research Subagia and Sadena (2015), Sumarna and Badrja (2016), and Jackie (2016) coupons have a negative effect on bond prices.

$>$ Sari and Sudjarni's research ( 2016 ) and Subagia and Sadena (2015) state that the maturity period has an influence on bond prices. Meanwhile, research conducted by Linda et al ( 2017 ) states that the maturity period has no effect on bond prices.

$>$ Subagia and Sedana ( 2015 ) and Linda et al ( 2017 ) in their research stated that the current ratio has an effect on bond prices but is different from the research of Dewi et al (2016), Sari and Sudjarni ( 2016 ) and Ompusunggu ( 2012 ) which state that the current ratio has no effect. against bond prices .

$>$ Sumarna and Badjra ( 2016 ) and Ompusunggu ( 2012 ) in their research stated that ratings have an effect on bond prices, but different research by Yanti ( 2016 ) states that ratings have no effect on bond prices.

Based on the existence of the phenomenon and the gap from research results - previous studies, it is necessary to do further research on the "Analysis Of Factors Affecting Bond Prices Traded On Indonesia Stock Exchange In The Period 2016-2018"

\section{THEORETICAL REVIEW}

\section{A. Bond Prices}

According to Fahmi (2015: 179) "Bonds are securities that are sold to the public, where there are various provisions that explain various things such as nominal value, interest rate, period, name of the issuer and several other provisions which are explained in the law which authorized by the relevant institutions. " 
The bond price is a price that has been agreed by the bond issuer and investors when they want to trade bonds on the capital market. Bond market prices always fluctuate due to the buying and selling activity of investors and are influenced by changes in the magnitude of macroeconomic variables such as inflation rates, interest rates, economic growth, the exchange rate of IDR / \$ and others. It is very important for investors to know the price of bonds so that investors know when they should buy or sell these bonds. Bond prices can be influenced by several factors including liquidity, maturity date and coupons.

\section{B. Coupons}

Coupons are the interest paid periodically by the issuer of the bonds to the holder (Tandelilin, 2010: 245). Bond coupons are generally paid every three months, both fixed and floating (Manurung, 2006: 11). namely

There are 4 ways to pay coupons (interest) in bonds,

$>$ Zero Coupon Bonds

$>$ Coupon Bonds

$>$ Fixed Coupon Bonds

$>$ Floating Coupon Bonds

\section{Maturity Period}

Maturity is the date on which the bondholder will get the repayment of the principal or the face value of the bonds he owns. The maturity period of the bonds varies from 365 days to more than 5 years. Bonds that will mature in 1 year are easier to predict, so they have less risk than bonds that have a maturity period of 5 years. In general, the longer the maturity of a bond, the higher the coupon or interest (Jakarta Stock Exchange, 2006).

According to Arthur J. Keown, et al (2011: 236), the time limit of a bond shows the length of time until the bond issuer to the bond holder and the expiration or redemption of the bond.

According to Fahmi (2015: 190), there are two forms of decisions in terms of time that are usually applied by the government and companies, namely: "Bonds with short term (short term) have lower interest rates than long-term bonds. For a period of 5 years, the market has absorbed the value of 1 billion US dollars with a yield (interest) of 10.5 percent. Meanwhile, for a period of 10 years the market absorbed 2 billion US dollars with a higher yield (interest) of 11.75 percent. "

\section{Current Ratio}

According to Kasmir (2016: 134) the current ratio is to measure the company's ability to pay short-term obligations or debts that are due immediately when they are collected as a whole. Meanwhile, according to Brigham and Houston (2013: 134) the current ratio is a ratio calculated by dividing current assets by current liabilities.

\section{E. Bond Rating}

The definition of a bond rating according to Moody's is a rating that describes both the possibility of default and the possibility of financial loss that will be suffered in the event of a default. Fahmi (2015: 184) argues that "Bonds sold to the public from the perspective of the buyers, see it based on ratings. The rating reflects the credible and prospect of buying the bonds as one of the company's current assets. Therefore, not just any bonds will be purchased, but bonds purchased are mainly based on recommendations from rating agencies that have been trusted and tested at the international level. "

\section{F. Framework}

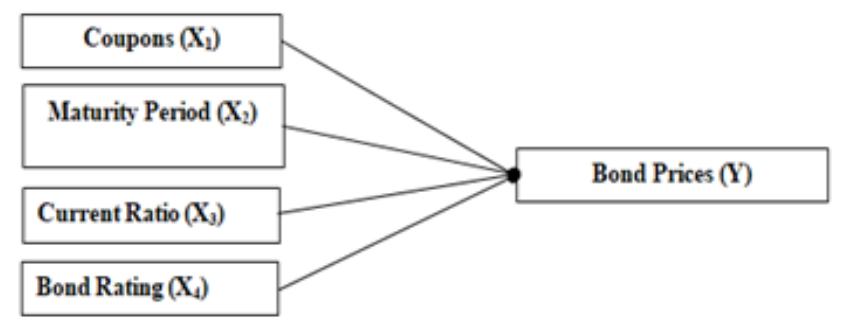

Fig 2:- Conceptual Framework

\section{G. Hypothesis}

The hypothesis is a temporary answer or provisional assumption to the research problem that has been formulated based on the theories used and is related to support the discussion of variables. The hypotheses put forward include:

$\mathrm{H}_{1}$ : It is assumed that coupons have a positive effect on bond prices

$\mathrm{H}_{2}$ : It is assumed that the maturity period has a positive effect on prices bond.

$\mathrm{H}_{3}$ : It is assumed that the current ratio has a positive effect on bond prices

$\mathrm{H}_{4}$ : It is assumed that the rating has a positive effect on bond prices

\section{METHODOLOGY}

\section{A. Type of Research}

This type of research is a quantitative study using the associative method, namely research that aims to test hypotheses and determine the relationship and influence between two or more variables on other variables. This study aims to examine the effect of the independent variables, namely coupons, maturity period, current ratio and bond rating on stock prices.

\section{B. Population and Sample}

The population in this study are all corporate bonds listed on the Indonesia Stock Exchange (BEI) and the Indonesian Bond Pricing Agency (IBPA) for the 20162018 period. The sampling technique used in this study was purposive sampling. Criteria certain defined by the author to obtain a representative sample . 
ISSN No:-2456-2165

\begin{tabular}{|c|c|c|c|}
\hline No. & Sample Criteria & Company & Bond \\
\hline 1 & $\begin{array}{c}\text { Corporate bonds traded on the Indonesia Stock Exchange } \\
\text { during 2016-2018 }\end{array}$ & 49 & 103 \\
\hline 2 & Companies included in the financial sector & (25) & (48) \\
\hline 3 & $\begin{array}{l}\text { Do not pay coupons in a fixed amount and there is a floating } \\
\text { rate effect on the bond price }\end{array}$ & 0 & 0 \\
\hline 4 & $\begin{array}{c}\text { The company did not publish consecutive financial } \\
\text { statements from 2016-2018 }\end{array}$ & (2) & (8) \\
\hline 5 & $\begin{array}{c}\text { The bonds are not listed in the rating issued by PT. Pefindo } \\
\text { during the 2014-2018 period }\end{array}$ & (2) & (2) \\
\hline & The total number of samples in the study & 20 & 45 \\
\hline
\end{tabular}

Table 2: - Research Sample

Source: Processed by researchers , 2019

\begin{tabular}{|c|c|c|c|}
\hline No. & Company & No. & Company \\
\hline 1 & $\begin{array}{c}\text { PT Sinar Mas Agro Resources and Technology } \\
\text { (SMART) Tbk }\end{array}$ & 11 & PT Indosat Tbk \\
\hline 2 & PT Antam Tbk & 12 & PT Telekomunikasi Indonesia Tbk \\
\hline 3 & PT Indofood Sukses Makmur Tbk & 13 & PT Express Trasindo Utama Tbk \\
\hline 4 & PT Mayora Indah Tbk & 14 & PT AKR Corporindo Tbk \\
\hline 5 & PT Agung Podomoro Land Tbk & 15 & PT Mitra Adiperkasa Tbk \\
\hline 6 & PT Bumi Serpong Damai Tbk & 16 & PT Pupuk Indonesia \\
\hline 7 & PT Summarecon Agung Tbk & 17 & PT Nippon Indosari Corpindo Tbk \\
\hline 8 & PT Adhi Karya Tbk & 18 & PT Modernland Realty Tbk \\
\hline 9 & PT Sumberdaya Sewatama & 19 & PT PP (Persero) Tbk \\
\hline 10 & PT Jasa Marga Tbk & 20 & PT Waskita Karya (Persero) Tbk \\
\hline
\end{tabular}

Table 3:- List of Company Samples

Source: Secondary data processed by the author

\section{Data Collection Methods}

Data collection methods used in this research are documentation and literature study methods. The data used are secondary data relating to coupon data, payment terms, current ratios, bond ratings and corporate bond prices in sample companies during the study period. The data is obtained from www.idx.co.id .

\section{Data analysis method}

Data analysis techniques in this study used descriptive statistical analysis, Panel Data Regression Analysis, Classical Assumption Test and Hypothesis Testing.

\section{RESULTS AND DISCUSSION}

\section{A. Descriptive Statistical Analysis Results}

\begin{tabular}{|c|c|c|c|c|c|}
\hline & $\mathrm{X} 1$ & $\mathrm{X} 2$ & $\mathrm{X} 3$ & $\mathrm{X} 4$ & $\mathrm{Y}$ \\
\hline Mean & 0.100956 & 4.870667 & 1.131593 & 3.456363 & 102.9987 \\
\hline Median & 0.102000 & 3.750000 & 1.056000 & 3,566000 & 102,9340 \\
\hline Maximum & 0.125000 & 24,50000 & 4.077000 & $4,839,000$ & 114.6180 \\
\hline Minimum & 0.070000 & 1,000000 & 0.241000 & 1,000000 & 93,52300 \\
\hline Std. Dev. & 0.012277 & 3.831193 & 0.728079 & 0.998922 & 3.730525 \\
\hline Skewness & -0.049314 & 2.883889 & 1.322092 & -0.406518 & 0.392705 \\
\hline Kurtosis & 2.790309 & 13,65849 & 5.210364 & 2.073587 & 3,557188 \\
\hline Jarque-Bera & & & & 8.545897 & 5.216210 \\
\hline Probability & 0.302049 & 826.1474 & 66,81047 & 0.013941 & 0.073674 \\
\hline Sum & 13.62900 & 657,5400 & 152.7650 & 466,6090 & 13904.82 \\
\hline Sum Sq. Dev. & 0.020196 & 1966,858 & 71.03332 & 133.7113 & 1864,854 \\
\hline Observations & 135 & 135 & 135 & 135 & 135 \\
\hline
\end{tabular}

Table 4:- Descriptive Statistics Results

Source: Data compiled by the author, 2020 
Based on table 4 , it can be explained as follows:

Coupons have a minimum value of 0.070000 and a maximum of 0.125000 with the mean (mean) of Coupons being 0.100956 . The standard deviation value shows a number of 0.012277 . The minimum value of 0.070000 comes from the Sumberdaya Sewatama I Series B Bonds, which were issued by PT. Sumberdaya Sewatama in 2016. The maximum value of 0.125000 comes from the Sustainable Bond I Podomoro Land Phase III issued by PT Agung Podomoro Land in 2016. The maximum value of 0.125000 also comes from the Sumberdaya Sewatama Bond II Bond Bkljt I Modernland Realty Thp I Series B issued by Modernland Realty Tbk in 2016. The average coupon value during 2016 - 2018 is 0.100956 . The standard deviation has a value of 0.012277 which is smaller than the mean value indicating that the data is homogeneous and has a low degree of deviation.

$>$ The maturity period has a minimum value of 1.000000 and a maximum of 24,50000 . This shows that the amount with the average ( mean ) of the Maturity Period is 4,870667 . The standard deviation value shows a number of 3.831193. The minimum value of 1.000000 comes from the Continuous Bonds I Antam Phase I Series A issued by PT. Antam Tbk in 2018. The maximum value of 24,50000 comes from the Obl Bkljt I Telkom Phase I Series D issued by PT Telekomunikasi Indonesia Tbk in 2016.. The average value of the maturity period during 2016 - 2018 is 4,870667 . The standard deviation has a value of 3.831193 which is smaller than the mean value indicating that the data is homogeneous and has a low degree of deviation.

> The Current Ratio has a minimum value of 0.241000 and a maximum of 4.077000 , with the average ( mean ) of the Current Ratio being 1.131593. The standard deviation value shows a number of 0.728079 . The minimum value of 0.241000 comes from the Series B Sumberdaya Sewatama I Bonds issued by PT. Sumberdaya Sewatama in 2016. The maximum value of 4.077000 comes from Bond I Express Trasindo Utama issued by PT. Express Trasindo Utama Tbk in 2016. The average value of the Current Ratio during 2016 - 2018 is 1.131593 . The standard deviation has a value of 0.728079 which is smaller than the mean value indicating that the data is homogeneous and has a low degree of deviation.

$>$ The bond rating has a minimum value of 1,000000 and a maximum of $4,839,000$, with the mean ( mean ) of the bond rating is 3,456363 . The standard deviation value shows a number of 0.998922 . The minimum value of 1,000000 comes from the Bond I Express Trasindo Utama issued by PT Express Trasindo Utama Tbk in 2016. The maximum value of 4,839,000 comes from the Sustainable Bond I Pp Phase II issued by PT. PP (PERSERO) Tbk in 2018. The average rating of bonds during 2016 - 2018 was 3,456363. The standard deviation has a value of 0.998922 which is smaller than the mean value indicating that the data is homogeneous and has a low degree of deviation.

$>$ The Bond Price has a minimum value of 93,52300 and a maximum of 114.6180 , with the average ( mean ) of the
Bond Price is 102,9987. The standard deviation value shows a number of 3.730525 . The minimum value of 93,52300 comes from the Sustainable Bonds I Adhi Phase II Series B issued by PT. Adhi Karya Tbk in 2016. The maximum value of 114.6180 comes from Indosat Obligatory Bkljt I Phase III Series D issued by PT. Indosat Tbk in 2017. The average value of bond prices during 2016 - 2018 is 102,9987. The standard deviation has a value of 3.730525 which is smaller than the mean value indicating that the data is homogeneous and has a low degree of deviation.

\section{B. Panel Data Regression Method}

The regression model estimation method using panel data in this study using the common effect model or pooled least square using the Chow Test approach . Following are the results of testing to estimate the panel data regression model with the Common Effect Model (CEM), Fixed Effect Model (FEM) and Random Effect Model (REM) approaches :

\section{$>$ Common Effect Model}

The results of testing the Common Effect Model (CEM) estimate in this study using Eviews 9 with the following results:

- Coupon variable $\left(\mathrm{X}_{1}\right)$ has a positive regression coefficient of 178,7200 with a p-value (sig) of $0.0000<\alpha 0.05$.

- The variable of maturity $\left(\mathrm{X}_{2}\right)$ has a positive regression coefficient of 0.356558 with a p-value (sig) of 0.0000 $<\alpha 0.05$.

- The variable Current Ratio $\left(\mathrm{X}_{3}\right)$ has a negative regression coefficient of -0.620194 with a p-value ( $\mathrm{sig}$ ) of $0.0241<\alpha 0.05$.

- The Bond Rating $\left(\mathrm{X}_{4}\right)$ variable has a positive regression coefficient of 1.072811 with a p-value (sig) of $0.0000<\alpha 0.05$.

- The F-statistic value is 66.76993 with a p-value (sig) of $0.000000<\alpha 0.05$. The calculated $F$ value is 66.76993> F table 2.44 and the p-value (sig) F is $0.000000<\alpha 0.05$ This means that this model is suitable for use in research.

- The R square value is 0.672610 or $67.26 \%$. \% . (67.26\% of the variation in bond prices can be explained by changes in coupons, maturity, Current Ratio, and Bond Rating and the rest is explained by variables outside of research).

\section{$>$ Fixed Effect Model}

Based on this assumption, the results of testing the fixed effects model use Eviews 9 with the following results:

- Coupon variable $\left(\mathrm{X}_{1}\right)$ has a positive regression coefficient of 179.9537 with p-value (sig) $0.0000<\alpha$ 0.05 .

- The variable of maturity $\left(\mathrm{X}_{2}\right)$ has a positive regression coefficient of 0.362955 with a p-value (sig) of 0.0000 $<\alpha 0.05$.

- The variable Current Ratio $\left(\mathrm{X}_{3}\right)$ has a negative regression coefficient of -0.616446 with a p-value (sig) of $0.0250<\alpha 0.05$. 
- The bond rating variable $\left(\mathrm{X}_{4}\right)$ has a positive regression coefficient of 1.084151 with a p-value (sig) of $0.0000<\alpha 0.05$.

- The F-statistic value is 44.92473 with a p-value (sig) $\mathrm{F}$ of $0.000000<\alpha 0.05$. F count $44.92473>\mathrm{F}$ table 2.44 and p-value (sig) F of $0.000000<\alpha 0.05$ This means that this model is suitable for use in research

- The R square value is 0.678027 or $67.8 \%$. (67.8\% of the variation in bond prices can be explained by changes in coupons, maturity period, Current Rat io, and Bond Rating and the rest is explained by variables outside of research).

\section{Random Effect Model}

The results of testing the Random Effect Model (REM) estimate using Eviews 9 with the following results:

- Coupon variable $\left(\mathrm{X}_{1}\right)$ has a positive regression coefficient of 176.8428 with a p-value (sig) of $0.0000<\alpha 0.05$.

- The variable of maturity $\left(\mathrm{X}_{2}\right)$ has a positive regression coefficient of 0.361378 with a p-value (sig) of 0.0000 $<\alpha 0.05$.

- The variable Current Ratio $\left(\mathrm{X}_{3}\right)$ has a negative regression coefficient of -0.572946 with a p-value ( $\mathrm{sig}$ ) of $0.0360<\alpha 0.05$.

- The Bond Rating variable $\left(\mathrm{X}_{4}\right)$ has a positive regression coefficient of 1.046284 with a p-value (sig) $0.0000<\alpha 0.05$.

- The F-statistic value is 63.16745 with a p-value (sig) F of $0.000000<\alpha 0.05$. F value count 63.16745> F table 2.44 and p-value (sig) $F$ of $0.000000<\alpha 0.05$ This means that this model is suitable for use in research

- The R square value is 0.680282 or $68 \%$. (as much as $68 \%$ of the variation in bond prices can be explained by changes in coupons, maturity date, Current Ratio, and
Bond Rating and the rest is explained by variables outside of research).

\section{Selection of Regression Models}

Of the three models that have been estimated, the most appropriate model will be selected or in accordance with the research objectives. There are three tests that are used as a tool in choosing the panel data regression model Common Effect, Fixed Effect, or Random Effect based on the characteristics of the data they have, namely:

- Chow Test to choose the best model between Common Effect and Fixed Effect .

- Hausman test to determine whether the most appropriate Fixed Effect and Random Effect are used .

- Langrange Multiplier test to select whether the Commont Effect or Random Effect model is more appropriate to be used in the panel data regression equation model .

\section{$>$ Chow test}

The test results Test Chow in this study using Eviews 9 with the result is the value of the cross section $\mathrm{F}$ probability is 0.3438 , thus the panel data method is right between the Common Effect Model (CEM) de ngan Fixed Effect Model (FEM) is a Common Effect Model (CEM) because the value of the cross section $\mathrm{F}$ probability is 0.3438 which means it is greater than the significance level $\alpha(5 \%)$, then $\mathrm{H} 0$ is accepted. Furthermore, if the Chow Test concludes to choose to use the Common Effect Model (CEM). Based Sriyana Jaka (2014), when the testing of Common Effect and Fixed Effect outcome Common Effect is better, then the test is completed. The Common Effect model is used for estimation used in the panel data regression equation model .

\section{Results of Panel Data Regression Analysis}

\begin{tabular}{|c|c|c|c|c|}
\hline \multicolumn{5}{|c|}{ Dependent Variable: Y } \\
\hline \multicolumn{5}{|c|}{ Method: Least Squares Panel } \\
\hline \multicolumn{5}{|c|}{ Date: $03 / 29 / 20$ Time: $3: 30 \mathrm{pm}$} \\
\hline \multicolumn{5}{|c|}{ Sample: 20162018} \\
\hline \multicolumn{5}{|c|}{ Periods included: 3} \\
\hline \multicolumn{5}{|c|}{ Cross-sections included: 45} \\
\hline \multicolumn{5}{|c|}{ Total panel (balanced) observations: 135} \\
\hline & & & & \\
\hline Variable & Coefficient & Std. Error & t-Statistic & Prob. \\
\hline & & & & \\
\hline $\mathrm{C}$ & 80,21299 & 1.773043 & 45,24029 & 0.0000 \\
\hline $\mathrm{X} 1$ & 178,7200 & 15.30500 & 11.67722 & 0.0000 \\
\hline $\mathrm{X} 2$ & 0.356558 & 0.051563 & 6.914991 & 0.0000 \\
\hline $\mathrm{X} 3$ & -0.620194 & 0.271709 & -2.282571 & 0.0241 \\
\hline $\mathrm{X} 4$ & 1.072811 & 0.201052 & 5.335978 & 0.0000 \\
\hline R-squared & 0.672610 & Mear & t var & 94.10424 \\
\hline Adjusted R-squared & 0.662536 & $\mathrm{SD}$ & var & 3.730525 \\
\hline
\end{tabular}


ISSN No:-2456-2165

\begin{tabular}{|c|c|c|c|}
\hline SE of regression & 2.167123 & Akaike info criterion & 4.421012 \\
\hline Sum squared resid & 610,5347 & Schwarz criterion & 4.528614 \\
\hline Log likelihood & -293.4183 & Hannan-Quinn criter. & 4,464738 \\
\hline F-statistic & 66.76993 & Durbin-Watson stat & 2.067146 \\
\hline Prob (F-statistic) & 0.000000 & & \\
\hline
\end{tabular}

Table 5:- Panel Data Regression Results

Source: Data compiled by the author, 2020

Based on the table above, the panel data regression equation is obtained as follows:

Yit $=80.21299+178.7200 \mathrm{X}_{1 \text { it }}+0.356558 \mathrm{X}_{2 \text { it }}{ }^{-}$

$0.620194 \mathrm{X}_{3 \text { it }}+1.072811 \mathrm{X}_{4 \text { it }}$

From the regression equation it can be concluded as follows:

$>$ The constant coefficient value is 80.21299 means that if the Coupon variable $\left(\mathrm{X}_{1}\right)$ Maturity Period $\left(\mathrm{X}_{2}\right)$, Current Ratio $\left(\mathrm{X}_{3}\right)$, and Bond Rating $\left(\mathrm{X}_{4}\right)$ are zero, then the amount of the Bond Price is 80.21299.

$>$ The regression coefficient value of Coupon variable $\left(\mathrm{X}_{1}\right)$ is positive, namely 178,7200 , meaning that every $1 \%$ increase in Coupons $\left(\mathrm{X}_{1}\right)$ is predicted to increase the bond price by 178,7200 assuming the other variables are fixed.

$>$ The regression coefficient value of the Maturity Period $\left(\mathrm{X}_{2}\right)$ variable is positive, namely 0.356558 , meaning that every $1 \%$ increase in the maturity period $\left(\mathrm{X}_{2}\right)$ is predicted to increase the bond price by 0.356558 assuming the other variables are fixed.

$>$ The regression coefficient value of the Current Ratio $\left(\mathrm{X}_{3}\right)$ variable is negative, which is 0.620194 , meaning that every $1 \%$ increase in the Current Ratio $\left(\mathrm{X}_{3}\right)$ is predicted to reduce the bond price by -0.620194 with the assumption that other variables remain.

$>$ The value of the Bond Rating variable regression coefficient $\left(\mathrm{X}_{4}\right)$ is positive at 1.072811 meaning that every $1 \%$ increase in Bond Rating $\left(\mathrm{X}_{4}\right)$ is predicted to increase the bond price by 1.072811 assuming the other variables are fixed.

\section{E. Classical Assumption Test}

\section{$>$ Normality Test Results}

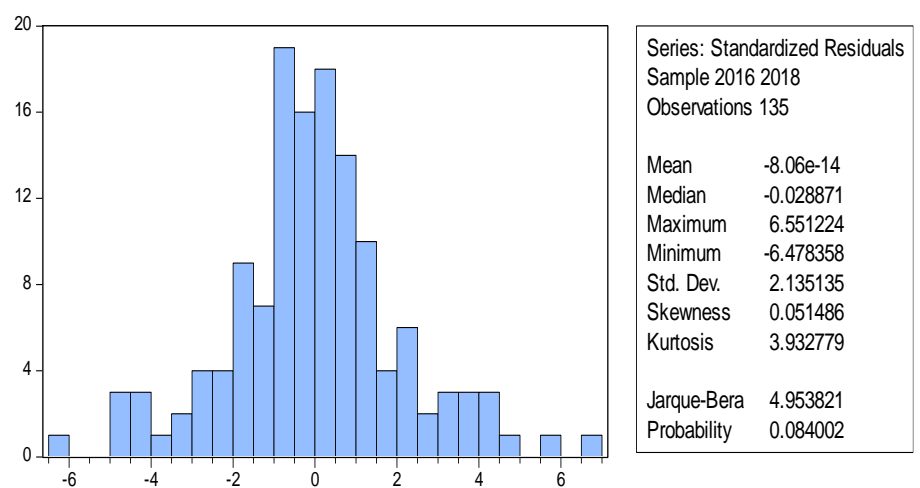

Fig. 3: - Normality Test Results

Source: Data compiled by the author, 2020
Based on Figure 3 shows that after testing the normality of the data using the Eviews 9 facility, all the variables in this model test show that the research above is normally distributed or it can be said that the requirements for normality can be met. This can be seen from Jarque Bera in this study of 4.953821 with a probability of 0.084002 greater than the 0.05 significance level. Therefore the research is normally distributed, so it can be said that the requirements for normality can be met.

\section{Multicolinearity Test Results}

The results of the multicolinearity test of data using the Eviews 9 facility can be obtained the value of the Coupon Centered VIF variable $\left(\mathrm{X}_{1}\right)$ Maturity Period $\left(\mathrm{X}_{2}\right)$, Current Ratio $\left(\mathrm{X}_{3}\right)$, and Bond Rating $\left(\mathrm{X}_{4}\right)$ less than 10 , so it can be It is concluded that in this study there are no symptoms of multicollinearity.

\section{Heteroscedasticity Test Results}

The results of the heteroscedasticity test with the Breusch-Pagan-Godfrey test in the table show the probability value of F-statistic $0.2451>$ from $\alpha(0.05)$ and it can be concluded that there is no heteroscedasticity problem in the research data.

\section{Autocorrelation Test Results}

The results of the autocorrelation test showed that the DW value generated from the regression model was 2.067146. Meanwhile, from the DW table with a significance of 0.05 and the amount of data $(\mathrm{n})=135$, and $\mathrm{k}=4$ ( $\mathrm{k}$ is the number of independent variables), the $\mathrm{dU}$ value is $1.7082 .4-\mathrm{du}=2.2918$, Seeing the DW and $4-\mathrm{du}$ values, it is concluded that there is no autocorrelation of the regression model.

\section{F. Hypothesis Testing \\ $>$ Determination Coefficient Test Results}

Based on the results of calculations using Eviews 9 obtained R-Squared coefficient of determination $\left(\mathrm{R}^{2}\right)$ equal to 0.672610 . This shows that the percentage effect of the Coupon $\left(\mathrm{X}_{1}\right)$ Maturity Period $\left(\mathrm{X}_{2}\right)$, Current Ratio $\left(\mathrm{X}_{3}\right)$, and Bond Rating $\left(\mathrm{X}_{4}\right)$ on the dependent variable Bond Price $(\mathrm{Y})$ is $67 \%$, whereas the remaining $33 \%$, influenced by other variables not explained in this study. 


\section{F Test Results}

\begin{tabular}{|c|c|c|c|}
\hline R-squared & 0.672610 & $\begin{array}{c}\text { Mean dependent } \\
\text { var }\end{array}$ & 94.10424 \\
\hline $\begin{array}{c}\text { Adjusted R- } \\
\text { squared }\end{array}$ & 0.662536 & SD dependent var & 3.730525 \\
\hline SE of regression & 2.167123 & $\begin{array}{c}\text { Akaike info } \\
\text { criterion }\end{array}$ & 4.421012 \\
\hline $\begin{array}{c}\text { Sum squared } \\
\text { resid }\end{array}$ & 610,5347 & Schwarz criterion & 4.528614 \\
\hline Log likelihood & -293.4183 & $\begin{array}{c}\text { Hannan-Quinn } \\
\text { criter. }\end{array}$ & 4,464738 \\
\hline F-statistic & $\mathbf{6 6 . 7 6 9 9 3}$ & Durbin-Watson stat & 2.067146 \\
\hline $\begin{array}{c}\text { Prob (F- } \\
\text { statistic) }\end{array}$ & $\mathbf{0 . 0 0 0 0 0 0}$ & & \\
\hline
\end{tabular}

Table 6:- F Statistic Test Results

Source: Data compiled by the author, 2020

Based on table 6, it is obtained the value of $F_{\text {statistic }} 66.76993>F_{\text {table }} 2.44$ with a significant 0.000 $<0.05$, thus Ho is rejected and $\mathrm{Ha}$ is accepted, meaning that simultaneously there is a positive and significant effect on Coupons $\left(\mathrm{X}_{1}\right)$, Maturity Period $\left(\mathrm{X}_{2}\right)$, Current Ratio $\left(\mathrm{X}_{3}\right)$, and Bond Rating $\left(\mathrm{X}_{4}\right)$ to the dependent variable Bond Price (Y).

\section{T test results}

\begin{tabular}{|c|c|c|c|c|}
\hline Variable & Coefficient & Std. Error & t-Statistic & Prob. \\
\hline C & 80,21299 & 1.773043 & 45,24029 & 0.0000 \\
\hline X1 & 178,7200 & 15.30500 & 11.67722 & 0.0000 \\
\hline X2 & 0.356558 & 0.051563 & 6.914991 & 0.0000 \\
\hline X3 & -0.620194 & 0.271709 & -2.282571 & 0.0241 \\
\hline X4 & 1.072811 & 0.201052 & 5.335978 & 0.0000 \\
\hline
\end{tabular}

Table 7:- Statistical T Test Results

Source: Data compiled by the author, 2020

Based on the results of these tests, the influence between variables can be explained as follows:

- Coupon variable $\left(\mathrm{X}_{1}\right)$ has a statistical $\mathrm{t}$ value of $11.67722>t_{\text {table }} 1.978$ with a significant value of $0.0000<0.05$ then $\mathrm{H} 0$ is rejected and $\mathrm{Ha}$ is accepted, which means that Coupons have a positive and significant effect on Bond Prices.

- The variable maturity period $\left(\mathrm{X}_{2}\right)$ has a statistical $\mathrm{t}$ value of $6.914991>\mathrm{t}_{\text {table }} 1.978$ with a significant value of $0.0000<0.05$, then $\mathrm{H} 0$ is rejected and $\mathrm{Ha}$ is accepted, meaning that there is a positive and significant effect of Maturity Period on prices bond.

- The variable Current Ratio $\left(\mathrm{X}_{3}\right)$ has a t statistical value of $2.282571>\mathrm{t}_{\text {table }}-1.978$ with a significant value of $0.0241<0.05$, then $\mathrm{H} 0$ is rejected and $\mathrm{Ha}$ is accepted, meaning that there is a significant negative effect of Current Ratio on bond prices.

- The Bond Rating variable $\left(\mathrm{X}_{4}\right)$ has a statistical value of $5.335978>\mathrm{t}_{\text {table }} 1.978$ with a significant value of $0.0000<0.05$, so $\mathrm{H} 0$ is rejected and Ha is accepted, meaning that there is a positive and significant effect of Bond Rating on bond prices.
G. Discussion of Research Results

\section{$>$ The Effect of Coupons on Bond Prices}

Based on the results of the statistical analysis of the Bond Coupon variable, the significance value is 0.0000 .The significance value is smaller than 0.05 and the regression coefficient is positive for 178.7200 , so it can be concluded that the Bond Coupon has a positive and significant effect on Bond Prices, so the first alternative hypothesis is accepted.

This hypothesis also supports Tandelilin (2010: 279), which states that coupons have a positive effect on bond prices, so that the high (low) coupon value of a bond will be the higher (lower) the price level of the bond. Sari and Sudjami (2016) in the study also expressed the same opinion that bond coupons have a positive and significant effect on Bond Prices.

\section{The Effect of Maturity Period on Bond Prices}

Based on the results of statistical analysis of the variable maturity period, the significance value is 0.0000 .The significance value is smaller than 0.05 and the regression coefficient is positive 0.356558 so that it can be concluded that the Maturity Period has a positive and significant effect on Bond Prices, so that the hypothesis the second alternative is accepted.

The results of this study support previous research conducted by Subagia and Sedana (2015) in which the results showed that the Period Maturity positive effect on the price corporate bonds.

\section{The Effect of Current Ratio on Bond Prices}

Based on the results of the statistical analysis of the Current Ratio variable, a significance value of 0.0241 is obtained.The significance value is less than 0.05 and the regression coefficient is negative -0.620194 so that it can be concluded that the Current Ratio has a significant negative effect on Bond Prices, so the third alternative hypothesis is rejected.

The results of this study support previous research conducted by Linda et al (2017) that the liquidity variable Current Ratio has a significant negative effect on the variable bond price. The results of this study support previous research conducted by Sari and Sudjarni (2016) that the liquidity variable has no effect on the price of corporate bonds on the Indonesia Stock Exchange.

\section{The Effect of Bond Ratings on Bond Prices}

Based on the results of the statistical analysis of the Bond Rating variable, the significance value is 0.0000.The significance value is less than 0.05 and the regression coefficient is positive 1.072811 so that it can be concluded that the Bond Rating has a positive and significant effect on Bond Prices, so the fourth alternative hypothesis is accepted. This shows that the increasing the company's rating can affect the increase in bond prices. A good rating on a company listed on the Indonesia Stock Exchange shows that the change has a low default rate so that it can affect the price of the bonds issued. 
The results of this study support previous research conducted by Sumarna and Badjra (2016) which stated that the rating variable has a positive and significant effect on the price of corporate bonds listed on the Indonesia Stock Exchange.

\section{CONCLUSIONS AND RECOMMENDATIONS}

\section{A. Conclusion}

$>$ Bond Coupons have a positive and significant effect on the price of bonds traded on the Indonesia Stock Exchange. The reason is because the higher the coupon offered by a bond, investors tend to buy the bond because it is considered to provide benefits and benefits to investors.

$>$ The maturity period has a positive and significant effect on the price of bonds traded on the Indonesia Stock Exchange. This is because investors have different preferences, so it is not certain that bonds with a longer maturity will be ignored because of the high risk they have. This is because investors already have confidence in the listed company, so that no matter how long the maturity date of a corporate bond is not a problem for investors.

$>$ Current Ratio has a negative and significant effect on the price of bonds traded on the Indonesia Stock Exchange. The reason is that the company's liquidity is not only supported by high current assets, but is also supported by the ability to book or provide profits for the company from year to year which is consistent and stable through high profits, because the company is not only oriented to short-term payments, but also oriented. long term payment. The effect of negative liquidity ratios on bond prices indicates that investors value the management of current assets and liabilities on the basis of a cash flow statement, which provides more detailed information.

$>$ Bond Rating has a positive and significant effect on Bond Prices traded on the Indonesia Stock Exchange. The reason is that the increasing corporate rating can affect the increase in bond prices. A good rating on a company listed on the Indonesia Stock Exchange shows that the change has a low default rate so that it can affect the price of the bonds issued

\section{B. Suggestions}

Based on the results of the discussion and conclusions regarding the variables which include Coupons, Maturity Period, Current Ratio and Bond Rating to the price of bonds traded on the Indonesia Stock Exchange in 20162018, the author tries to convey some suggestions for further research as follows:

$>$ Companies as bond issuers are advised to pay attention to the factors that affect bond prices, especially coupons, maturity and bond ratings in order to provide an appropriate price release for the bonds issued. By paying attention to factors, one of which is increasing the bond rating can maintain investor confidence. This is because these variables are proven to have an effect on Bond Prices.
For further researchers, in order to increase the study period and the number of samples so that the results of the study can accurately represent the conditions that occur, add other variables that can affect bond prices, such as inflation and economic growth as external factors and duration of internal factors and to analyze the influence of variable variables. the same or any other variable. Further researchers can also conduct research on other types of bonds such as government bonds because they have different characteristics from bonds in this study

\section{REFERENCES}

[1]. Achmad, Komarudin, Imam Subekti dan Sari Atmini, 2007. Investigasi Motivasi dan Strategi Manajemen Laba pada Perusahaan Publik di Indonesia. Simposium Nasional Akuntansi 10 Makassar.

[2]. Anandasari, Luh Putu SK. Dan Luh Komang S, 2017, Pengaruh Likuiditas, Waktu Jatuh Tempo, Dan Kupon Terhadap Perubahan Harga Obligasi Korporasi Di Bei; Jurnal ISSN, Vol.6 No.6; Pp 3283-3313.

[3]. Boardman, Calvin M. and Richard W. McEnally, 1981, Factors Affecting Seasoned Corporate Bond Prices.

[4]. Brealey, Richard A., Stewart C M., dan Alan J. Marcus. 2008. Dasar-dasar Manajemen Keuangan Perusahaan. Jilid Satu. Jakarta: Erlangga.

[5]. Brigham, Eugene F.dan Joul F Houston. 2013. Dasardasar Manajemen.Keuangan. Jakarta: Salemba Empat.

[6]. Dewi, Ni Putu GK. Dkk, 2016, Pengaruh Suku Bunga, Nilai Tukar, Coupon Rate, Dan Likuiditas Obligasi Terhadap Harga Pasar Obligasi Pada Sektor Keuangan; E-Jurnal Manajemen Unud,Vol.5 No.5; Pp 2898-2927.

[7]. Fahmi, Irham, 2015. Pengantar Manajemen Keuangan Teori dan Soal. Jawab.

[8]. Bandung: Alfabeta.

[9]. Kasmir, 2016, Analisis Laporan Keuangan. Jakarta: PT Raja Grafindo.

[10]. Keown, Arthur J., John D. M., J. William Petty, dan David F. Scott Jr. 2011. Manajemen Keuangan: Prinsip dan Penerapan. Jilid Satu. Edisi Kesepuluh. Jakarta: PT Indeks.

[11]. Manurung, Adler Haymans. 2006. Dasar-dasar Investasi Obligasi. Jakarta: PT. Elex Media Komputindo.

[12]. Ompusunggu, Arles Parulian, 2010, Pengaruh Atribut Obligasi, Tingkat Bunga Dan Nilai Tukar Rupiah Terhadap Harga Obligasi Di Indonesia, Jurnal Bisnis Dan Manajemen; Pp 63-66.

[13]. Pramono, Cahyo dan Irawan, 2017, Analisis FaktorFaktor Harga Obligasi Perusahaan Keuangan Di Bursa Efek Indonesia; Jurnal ISSN, Vol. 8 No.1 (Juli); Pp 62-78.

[14]. Sari, Ni Komang DP., dan Luh Komang Sudjarni. 2016. Pengaruh Likuiditas Obligasi, Waktu Jatuh Tempo, dan Kupon Obligasi terhadap Perubahan Harga Obligasi Korporasi Berperingkat. Jurnal Manajemen Universitas Udayana. Vol. 5. No. 4. h. 
2283-2310.

[15]. Subagia, I Ketut., dan Ida Bagus Panji Sedana. 2015. Analisis Pengaruh Likuiditas, Waktu Jatuh Tempo dan Kupon Obligasi Terhadap Perubahan Harga Obligasi Korporasi di Bursa Efek Indonesia (BEI). Jurnal Manajemen Universitas Udayana. Vol. 4 No. 5. H.1451-1465.

[16]. Sumarna, I Wayan dan Ida Bagus Badjra, 2016, Pengaruh Rating, Maturitas, Tingkat Suku Bunga Dan Kupon Terhadap Perubahan Harga Obligasi Korporasi Di Bursa Efek Indonesia; E Jurnal Manajemen Unud, Vol. 5 No.12; Pp 2302-8912.

[17]. Tandelilin, Eduardus. 2010. Portofolio dan Investasi. Edisi Pertama. Yogyakarta: Kanisius.

[18]. Yanti, 2016, Analisis Pengaruh Peringkat, Maturitas, dan Kupon Obligasi Terhadap Harga Obligasi di Bursa Efek Indonesia. Fakultas Ekonomi dan Bisnis Universitas Tanjungpura.

[19]. Yuan, Kathy. 2001. The Liquidity Service of Sovereign Bonds, Working Paper, didownload dari www.papers.ssrn.com. 